\title{
Actinosporean infections in oligochaetes in a river system in southwest Ireland with descriptions of three new forms
}

\author{
C. Negredo*, M. F. Mulcahy \\ Department of Zoology \& Animal Ecology, National University of Ireland, Lee Maltings, Prospect Row, Cork, Ireland
}

\begin{abstract}
Sediment samples were collected in April, June and August 1998 from a river in southwest Ireland. A total of 1836 oligochaete specimens were collected from these sediments, and examined for actinosporean infections. Actinosporean-infected oligochaetes have been determined, symptoms and course of infection have been considered and the spores released from them have been described. Spore characteristics for each actinosporean were defined and the prevalence of infection in each oligochaete species was also determined. The overall prevalence of infection with actinosporeans within the oligochaete sample was $\sim 2 \%$. Seven types were distinguished, belonging to echinactinomyxon, aurantiactinomyxon and neoactinomyxum forms, from Tubifex ignotus, Lumbriculus variegatus and Limnodrilus hoffmeisteri, and compared with actinosporean types previously reported in the literature. Three of these forms have not been previously described, while the other 4 are morphologically and morphometrically similar to known forms. These actinosporeans may be stages in myxozoan life cycles.
\end{abstract}

KEY WORDS: Actinosporean · Myxosporean · Oligochaete

\section{INTRODUCTION}

Until recently, the class Actinosporea was included in the myxozoan group as an independent class of the Myxosporea. Wolf \& Markiw (1984) demonstrated the involvement of an actinosporean triactinomyxon in the life cycle of a myxosporean species Myxobolus cerebralis. These authors showed that the life cycle of $M$. cerebralis involves transformation of the spore stage to an actinosporean stage in an oligochaete host Tubifex tubifex. Since then, similar life cycles involving an actinosporean stage and an annelid host have been demonstrated for other myxosporean species (El-Matbouli \& Hoffmann 1989, 1993, Ruidish et al. 1991, ElMatbouli et al. 1992, Großheider \& Körting 1992, Benajiba \& Marques 1993, Kent et al. 1993, Yokoyama et al. 1993a, 1995, Uspenskaya 1995, Bartholomew et al.

*E-mail: c.negredo@ucc.ie
1997, El-Mansy \& Molnar 1997, Yokoyama 1997, Székely et al. 1998, Molnar et al. 1999, Özer \& Wootten 2000). These results, showing the actinosporeans to be stages in the life cycle of species of Myxosporea, led to the suppression of the class Actinosporea (Kent et al. 1994).

Many myxosporean parasite species are responsible for important economic losses and are a potential threat to cultured fish species, while some myxosporean species such as Myxobolus cerebralis are also important parasites in the wild. Since the publication of Wolf \& Markiw (1984), interest in the actinosporean group has grown, and while some myxoporean parasites have now been linked to actinosporean stages by transmission experiments in the laboratory, the development and life cycles of others are unknown. Little is known about the actinosporean stage itself (Marques 1984, Yokoyama et al. 1993b). Incomplete descriptions of these stages have been published in the earlier literature. More accurate descriptions, and information on 
the ecology of the oligochaete hosts, have been reported more recently (McGeorge et al. 1997, El-Mansy et al. 1998, Oumouna 1998, Xiao \& Desser 1998a,b,c).

Myxosporean infections are common in wild fish populations, usually with high prevalence and wide distribution (Lom \& Dykova 1992). There are an increasing number of newly recognised myxosporean species, as well as others previously described, for which the life cycle remains unknown. These are species that may not have been considered a problem before now, but which may become a concern in the future. Therefore, more actinosporean forms need to be described and the general ecology of this hostparasite system (i.e. oligochaete-actinosporean-fish) requires elucidation. Such knowledge may help to provide information on further links between actinosporeans and myxosporean species, as well as a basis for effective control of myxosporean-induced pathology.

The purpose of this study was to investigate the actinosporean fauna associated with oligochaetes of a river system in south-west Ireland, where several myxosporean species have been previously recorded. These myxosporean species, the life cycles of which are unknown, were found widely distributed in the wild fish of this river (O'Flynn 1998). Detailed descriptions of actinosporeans and data on the prevalence of infections in the oligochaete community are presented. The actinosporeans are described following the guidelines of Lom et al. (1997). The results of the study supply data for further investigation of actinospore/myxosporean links and possible myxosporean life cycles.

\section{MATERIALS AND METHODS}

Sampling sites and collection of sediments. Samples were collected from the lower reaches of the Cloonee river system in south-west Ireland (Fig. 1). The study performed by O'Flynn (1998) showed that infection by extrasporogonic myxosporean stages, observed in wild fish, began in April and was present during the summer to early autumn. Extrasporogonic myxosporean stages were highly prevalent in spring and summer. Based on these findings, sampling in this study was carried out between April and August, when the presence of the infective stages in the environment was expected. Using a grab sampler, sediments were collected in early April, mid-June and late August 1998. The samples were taken from 2 slow-flowing depositing sites (site 1, grid ref. V795635; site 2, grid ref. V781683) (Fig. 1), which had high oligochaete population densities. A higher amount of organic plant material was visible in samples collected at site 2 than at site 1 . The material was transported to the lab in plas-

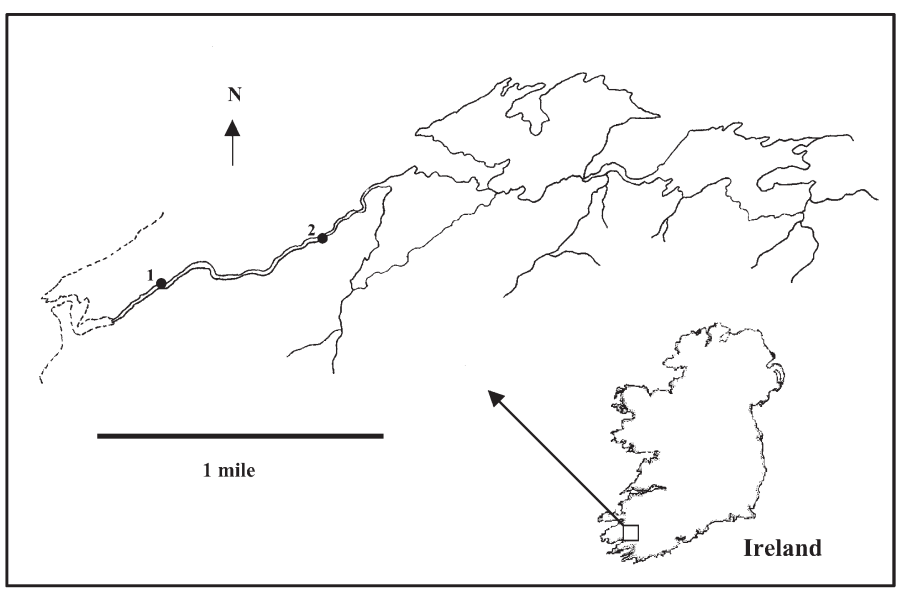

Fig. 1. Map of the Cloonee river system showing sampling sites 1 and 2. 1 mile $=1.609 \mathrm{~km}$

tic bags containing a small amount of river water. On arrival, sediments were placed into aerated containers until examination.

Oligochaete isolation and examination for actinosporean infection. Oligochaetes were isolated from the sediments by gently washing the sediments through a wire $500 \mu \mathrm{m}$ mesh sieve that removed large particles and debris. The material retained in the sieve was washed into trays and examined for the presence of oligochaetes. Oligochaetes were then individually isolated into 96-well culture plates with $200 \mu$ filtered dechlorinated tap water per well (Yokoyama et al. 1991). Water in the wells was changed twice weekly. Over a period of about 2 mo, oligochaetes were examined daily for the release of actinosporeans, using an inverted binocular microscope (Nikon TMS-F).

Actinosporean infection: prevalence and identification of the actinosporean types. Prevalence of infection of each actinosporean type (i.e. percentage of infected oligochaetes) was calculated for each host species and for the whole community, for each complete sample and sampling periods, and for the total of samples. Released actinosporeans were removed from wells using a plastic pipette. Actinosporeans were measured, photographed, drawn and identified. Measurements designated by Lom et al. (1997) were taken from a variable number of spores, depending on availability, for each actinosporean type using an ocular micrometer. Mean, standard deviation and range of characteristics of each spore were calculated. Parasites were photographed under a phase contrast binocular microscope (Nikon optiphot with AFX-IIA light meter and FX-35WA camera). Spores were identified using the keys of Janiszewska $(1955,1957)$ and Marques (1984) and by comparing with forms from published reports. 
Histology. Highly infected oligochaetes were fixed in $4 \%$ buffered formalin and then embedded in paraffin. Sections measuring 3 to $4 \mu \mathrm{m}$ in thickness were stained with haematoxylin and eosin and examined under a phase contrast binocular microscope (Nikon), to determine the location of spore development.

Identification of oligochaete species. Representative oligochaete species from each sampling site were fixed in $4 \%$ formalin for $48 \mathrm{~h}$, and then stored in $70 \%$ alcohol until examination. For identification, they were cleared for a few hours, mounted in polyvinyl lactophenol before examination and identified following the keys of Brinkhurst (1971). Species composition at each site was defined as the percentage of each species in the total oligochaete sample.

\section{RESULTS}

\section{Oligochaete population}

A total of 1836 oligochaete specimens were isolated from sediments collected at both sites. The oligochaete population included members of the Tubificidae, Lumbriculidae, Naidididae and Enchytraeidae families (Table 1).

The highest number of collected specimens belonged to the Tubificidae (93.56\%), the greatest proportion of which were members of the genus Limnodrilus. Of these, $87 \%$ were immature specimens, preventing identification to species level. Mature Limnodrilus specimens were identified as $L$. hoffmeisteri $(1.1 \%)$. A total of $6.15 \%$ of the isolated tubificids were identified as T. ignotus. Their composition varied between sites: a higher number of $T$. ignotus were isolated from sediments collected at site 2, where more plant material was present. The remaining tubificid specimens were identified as Aulodrilus plurisetae $(8.41 \%)$.

Table 1. Oligochaete population (no. of oligochaetes examined $=1836$ )

\begin{tabular}{|c|c|c|}
\hline $\begin{array}{l}\text { Oligochaete } \\
\text { families }\end{array}$ & $\begin{array}{l}\text { Oligochaete } \\
\text { species }\end{array}$ & $\begin{array}{l}\text { Species compo- } \\
\text { sition }(\%)\end{array}$ \\
\hline Tubificidae & $\begin{array}{l}\text { Aulodrilus pluriseta } \\
\text { Tubifex ignotus } \\
\text { Limnodrilus spp. }^{\text {a }} \\
\text { Limnodrilus hoffmeisteri }^{\text {b }}\end{array}$ & $\begin{array}{r}8.41 \\
6.15 \\
77.90 \\
1.10\end{array}$ \\
\hline Lumbriculidae & Lumbriculus variegatus & 3.64 \\
\hline Naididae & $\begin{array}{l}\text { Aulophorus furcatus, } \\
\text { Dero sp., Nais sp. }\end{array}$ & 2.00 \\
\hline Enchytraeidae & 1 species (indeterminate) & 0.80 \\
\hline
\end{tabular}

Only 1 species from each of the Enchytraeidae and Lumbriculidae families was isolated from the sediments. Lumbriculid specimens were identified as Lumbriculus variegatus $(3.64 \%)$. These were more abundant at site 1 than site 2. Very few Enchytraeidae were observed at either site. Naididae species composition consisted of Dero sp., Nais sp. and Aulophorus furcatus, which together comprised $2 \%$ of the entire oligochaete sample.

\section{Actinosporean infection}

No actinosporeans were released by the species recorded from the Naididae and the Enchytraeidae families. Aulodrilus plurisetae and immature Limnodrilus species were also uninfected during the whole study. Seven different actinosporean types were isolated from the oligochaetes Lumbriculus variegatus, Tubifex ignotus and mature Limnodrilus hoffmeisteri. They belonged to the echinactinomyxon, aurantiactinomyxon and neoactinomyxum forms. Individual infected oligochaetes released actinosporeans over a period of about $2 \mathrm{wk}$ in the laboratory. The overall prevalence of infection with actinosporeans was $\sim 2 \%$. Oligochaetes infected by actinosporeans were recorded on all 3 sampling occasions. The highest prevalence of infection $(4.9 \%)$ was recorded in samples from April. A prevalence of $1.4 \%$ was detected in June and $1.1 \%$ in August (Table 2).

The oligochaete Tubifex ignotus was found to be infected by 2 forms of aurantiactinomyxon (1 and 3). Aurantiactinomyxon 1 infection in T. ignotus was the most prevalent infection recorded during the study. A total of 27 out of 113 T. ignotus (23.8\%) were infected by aurantiactinomyxon 1 . Aurantiactinomyxon 3 was observed in only 1 case $(0.8 \%)$. Lumbriculus variegatus were found to harbour different actinosporeans of echinactinomyxon and neoactinomyxum forms. Of the 67 L. variegatus specimens collected, 4 were infected by echinactinomyxon forms; echinactinomyxon 1 and 3 were each found in 1 Lumbriculus variegatus $(1.5 \%)$,

Table 2. Prevalence of actinosporeans in oligochaetes, number of infected oligochaetes and number of isolated oligochaetes for each sampling time and for the total study (AprilJune-August)

\begin{tabular}{|lccc|}
$\begin{array}{l}\text { Sampling } \\
\text { times }\end{array}$ & $\begin{array}{c}\text { No. of infected } \\
\text { oligochaetes }\end{array}$ & $\begin{array}{c}\text { No. collected } \\
\text { oligochaetes }\end{array}$ & $\begin{array}{c}\text { Prevalence } \\
\text { of infection (\%) }\end{array}$ \\
\hline April & 21 & 427 & 4.9 \\
June & 7 & 489 & 1.4 \\
August & 11 & 920 & 1.1 \\
Whole study & 39 & 1836 & 2.1 \\
\hline
\end{tabular}


Table 3. Prevalence of actinosporean infection in infected oligochaetes species found in the whole study

\begin{tabular}{|llcrc|}
\hline Actinosporean form & $\begin{array}{c}\text { Oligochaete host } \\
\text { species }\end{array}$ & $\begin{array}{c}\text { No. of host } \\
\text { specimens }\end{array}$ & $\begin{array}{c}\text { No. of infected } \\
\text { specimens }\end{array}$ & $\begin{array}{c}\text { Prevalence of } \\
\text { infection (\%) }\end{array}$ \\
\hline Echinactinomyxon 1 & L. variegatus & 67 & 1 & 1.5 \\
Echinactinomyxon 2 & L. variegatus & 67 & 2 & 3 \\
Echinactinomyxon 3 & L. variegatus & 67 & 1 & 1.5 \\
Aurantiactinomyxon 1 & T. ignotus & 113 & 27 & 1 \\
Aurantiactinomyxon 3 & T. ignotus & 113 & 3 & 0.8 \\
Aurantiactinomyxon 2 & L. hoffmeisteri & 21 & 4 & 5.9 \\
Neoactinomyxum & L. variegatus & 67 & & \\
a Mature specimens only & & & & \\
\hline
\end{tabular}

and echinactinomyxon 2 in 2 L. variegatus (3\%). The neoactinomyxum form was detected in 4 specimens of L. variegatus (5.9\%). Limnodrilus hoffmeisteri was infected by only 1 aurantiactinomyxon form; 3 out of 21 L. hoffmeisteri specimens isolated (only mature specimens identified) were found to be infected by aurantiactinomyxon 2 (14.2\%) (Table 3).

Aurantiactinomyxon form 1 was found in all 3 sampling periods and was the most common type of spore observed. Prevalence of aurantiactinomyxon 1 infection in Tubifex ignotus specimens was $56.6 \%$ for sediments collected in April, 9\% in June and 14\% in August. T. ignotus infected with aurantiactinomyxon 1 were detected at site 2 only. Aurantiactinomyxon 3 was found in August at site 2; prevalence of infection by aurantiactinomyxon 3 was $2 \%$. Limnodrilus hoffmeisteri specimens infected by aurantiactinomyxon 2 were found in sediments collected in April and June at both sites. Prevalence of infection was $11.1 \%$ and $25 \%$ respectively (only mature oligochaete specimens included in calculation of prevalence). At site 1 Lumbriculus variegatus specimens infected by echinoactinomyxon forms 1 and 2 were found in April and form 3 in August. Prevalence of infection was $7.1 \%$ for form echinactinomyxon 1, $18.8 \%$ for form 2 and $5.8 \%$ for form 3 . A neoactinomyxum form was observed in June $(5.5 \%)$ and August $(11.7 \%)$ in L. variegatus. Specimens infected by both echinactinomyxon and neoactinomyxum types were found only at site 1 (Table 4). Prevalence of infection for each actinospore found in the total oligochaete population is given in Table 5 (independent of oligochaete species). The aurantiactinomyxon form 1 was again the most prevalent infection found in the whole study, and highest prevalence was in April. Although both L. variegatus and T. ignotus released different types of actinosporeans, no mixed infections were detected in these oligochaetes. Darkening was a characteristic feature in those $L$. variegatus species infected with the neoactinomyxum form.

\section{Actinosporean stage description}

As a result of this study, 7 forms have been described: 3 forms of aurantiactinomyxon, 3 of echinactinomyxon and 1 of the neoactinomyxum groups. The actinosporeans are described following the guidelines of Lom et al. (1997).

\section{Aurantiactinomyxon forms}

Three actinosporean types showed morphological similarity with forms of aurantiactinomyxon. These forms were style-less with 3 caudal processes, which at their bases enclosed the spore body.

Table 4. Actinosporean prevalence in each host species on the 3 sampling occasions; April (Ap.), June (J), and August (A) and sites at which oligochaete infected specimens were recorded

\begin{tabular}{|c|c|c|c|c|c|c|c|c|}
\hline \multirow[t]{2}{*}{ Host species } & \multirow[t]{2}{*}{ Actinosporean form } & \multirow[t]{2}{*}{ Site } & \multicolumn{3}{|c|}{$\begin{array}{l}\text { No. isolated host } \\
\text { specimens }\end{array}$} & \multicolumn{3}{|c|}{$\begin{array}{l}\text { Prevalence of } \\
\text { infection (\%) }\end{array}$} \\
\hline & & & Ap. & $\mathrm{J}$ & $\mathrm{A}$ & Ap. & $\mathrm{J}$ & A \\
\hline \multirow{4}{*}{$\begin{array}{c}\text { Lumbriculus } \\
\text { variegatus }\end{array}$} & Echinactinomyxon 1 & 1 & 14 & 36 & 17 & 7.1 & 0 & 0 \\
\hline & Echinactinomyxon 2 & & 14 & 36 & 17 & 18.8 & 0 & 0 \\
\hline & Echinactinomyxon 3 & & 14 & 36 & 17 & 0 & 0 & 5.8 \\
\hline & Neoactinomyxum & & 14 & 36 & 17 & 0 & 5.5 & 11.7 \\
\hline \multirow{2}{*}{$\begin{array}{l}\text { Tubifex } \\
\text { ignotus }\end{array}$} & Aurantiactinomyxon 1 & 2 & 30 & 33 & 50 & 56.6 & 9 & 14 \\
\hline & Aurantiactinomyxon 3 & & 30 & 33 & 50 & 0 & 0 & 2 \\
\hline $\begin{array}{l}\text { Limnodrilus } \\
\text { hoffmeisteri }\end{array}$ & Aurantiactinomyxon 2 & 1,2 & 9 & 8 & 4 & 11.1 & 25 & 0 \\
\hline
\end{tabular}


Table 5. Prevalence of infection, from each sampling time and in total, found in the total oligochaete sample

\begin{tabular}{|lcccc|}
\hline Actinosporean form & $\begin{array}{c}\text { Prevalence infection } \\
(\%) \text { (whole study) } \\
\mathrm{n}=1836\end{array}$ & $\begin{array}{c}\text { Prevalence infection } \\
(\%) \text { (April) } \\
\mathrm{n}=427\end{array}$ & $\begin{array}{c}\text { Prevalence infection } \\
\text { (\%) (June) } \\
\mathrm{n}=489\end{array}$ & $\begin{array}{c}\text { Prevalence infection } \\
\text { (\%) (August) } \\
\mathrm{n}=920\end{array}$ \\
\hline Aurantiactinomyxon 1 & 1.47 & 3.98 & 0.61 & 0.76 \\
Aurantiactinomyxon 2 & 0.16 & 0.23 & 0.40 & 0 \\
Aurantiactinomyxon 3 & 0.05 & 0 & 0 & 0.10 \\
Echinactinomyxon 1 & 0.05 & 0.23 & 0 & 0 \\
Echinactinomyxon 2 & 0.10 & 0.46 & 0 & 0.10 \\
Echinactinomyxon 3 & 0.05 & 0 & 0.40 & 0.21 \\
Neoactinomyxum & 0.21 & 0 & & 0 \\
\end{tabular}

\section{Actinosporean form:}

aurantiactinomyxon 1 -Figs. 2(A) \& 3(A)

\section{Host: $\quad$ Tubifex ignotus}

Description and measurements based on 43 organisms: Aurantiactinomyxon 1 was characterised by 3 caudal processes that were 21.1 $\pm 1 \mu \mathrm{m}$ long (range, 18.2-23.4 $\mu \mathrm{m}$ ) and $16.1 \pm 2.1 \mu \mathrm{m}$ wide (range, 13-19.5 $\mu \mathrm{m}$ ) at the base. The caudal processes, wider at its medium region than at the bases, were tapering to a point. The processes were of equal length and slightly curved downward. The spore body, spherical in shape, was $14.4 \pm 1.3 \mu \mathrm{m}$ in diameter (range, 12.6-16.9 $\mu \mathrm{m}$ ). A multinucleated sporoplasm was enclosed in the spore cavity. Up to 10 sporoplasmic germs were located within the sporoplasmic mass. Polar capsules were almost spherical and measured $3 \pm 0.3 \mu \mathrm{m}$ in diameter (range, 2.5-3.9 $\mu \mathrm{m}$ ) (Table 6). Pansporocysts with actinosporean stages were found in the gut epithelium of the oligochaete in the posterior half of the intestine. Early and mature pansporocysts were observed between the epithelial cells; in the mature pansporocyst, developing spores with polar capsules and sporoplam cells were visible (Fig. 4).

\section{Actinosporean form:}

aurantiactinomyxon 2-Figs 2(B) \& 3(B,C)

Host: $\quad$ Limnodrilus hoffmeisteri

Description and measurements based on 12 organisms: Spore body was spherical with 3 polar capsules, also spherical. Mean size of the spore body was $14.1 \pm$ $1.3 \mu \mathrm{m}$ (range, 13 to $15.6 \mu \mathrm{m}$ ). Polar capsules measured $2.7 \pm 0.2 \mu \mathrm{m}$ (range, 2.6 to 3.1). Caudal processes were of equal length and slightly rounded at the ends. These were $31 \pm 3.7 \mu \mathrm{m}$ long (range, 26 to $36 \mu \mathrm{m}$ ). Mean width was $10.6 \pm 1.1 \mu \mathrm{m}$ (range, 9.1 to $13 \mu \mathrm{m}$ (Table 6). Sporoplasmic mass contained $\sim 12$ germ cells. Pansporocysts were found located in the intestinal epithelium of the infected oligochaete.

\section{Actinosporean form:}

aurantiactinomyxon 3-Figs 2(C) \& 3(D)

Host:

Tubifex ignotus
Description and measurements based on 4 organisms: These types looked similar to aurantiactinomyxon form 1, except that the spore body was smaller, and 1 caudal process was of equal size but differed in shape, having a rounded distended end. These spores were found in only 1 oligochaete and in very low numbers. Length and width of the spore body was $\sim 9.1 \mu \mathrm{m}$. The sporoplasmic mass contained $\sim 10$ infective cells. Caudal processes were about $20.8 \pm$ $1.8 \mu \mathrm{m}$ in length (range, 18.2 to $23.4 \mu \mathrm{m}$ ) and $10.4 \mu \mathrm{m}$ in width. Polar capsules measurements could not be ascertained (Table 6). Pansporocysts were found located in the intestinal epithelium of the infected oligochaete.
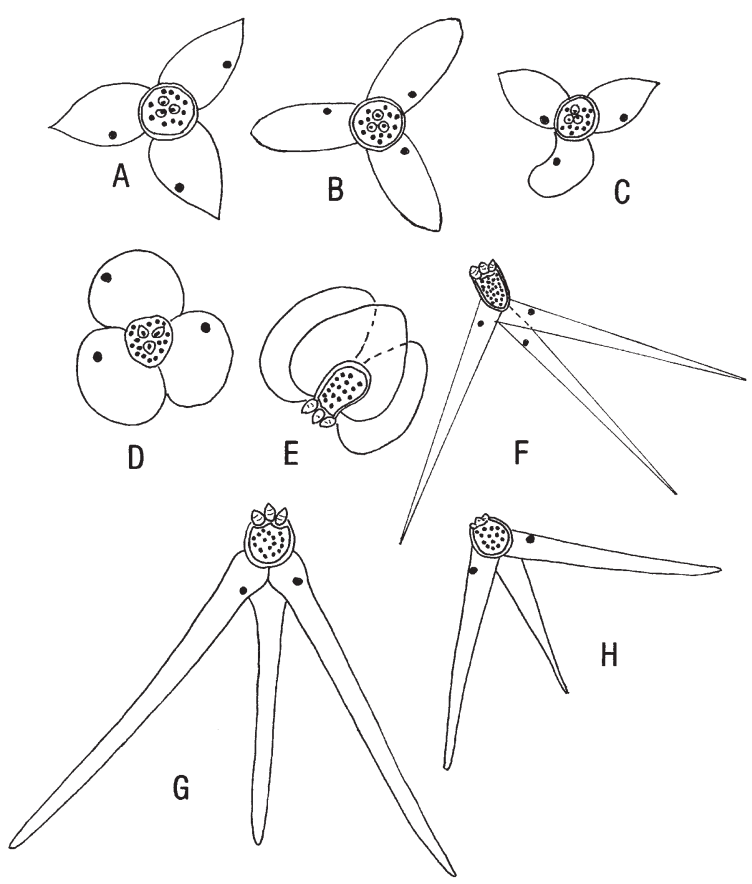

Fig. 2. Schematic drawings of actinosporean types found in the river system. (A-C) Aurantiactinomyxon; (A) type 1, (B) type 2, (C) type 3. (D-E) Neoactinomyxum; (D) apical view, (E) lateral view. $(\mathrm{F}-\mathrm{H})$ Echinactinomyxon forms; $(\mathrm{F})$ type 2, (G) type 1, (H) type 3. (Not to scale) 


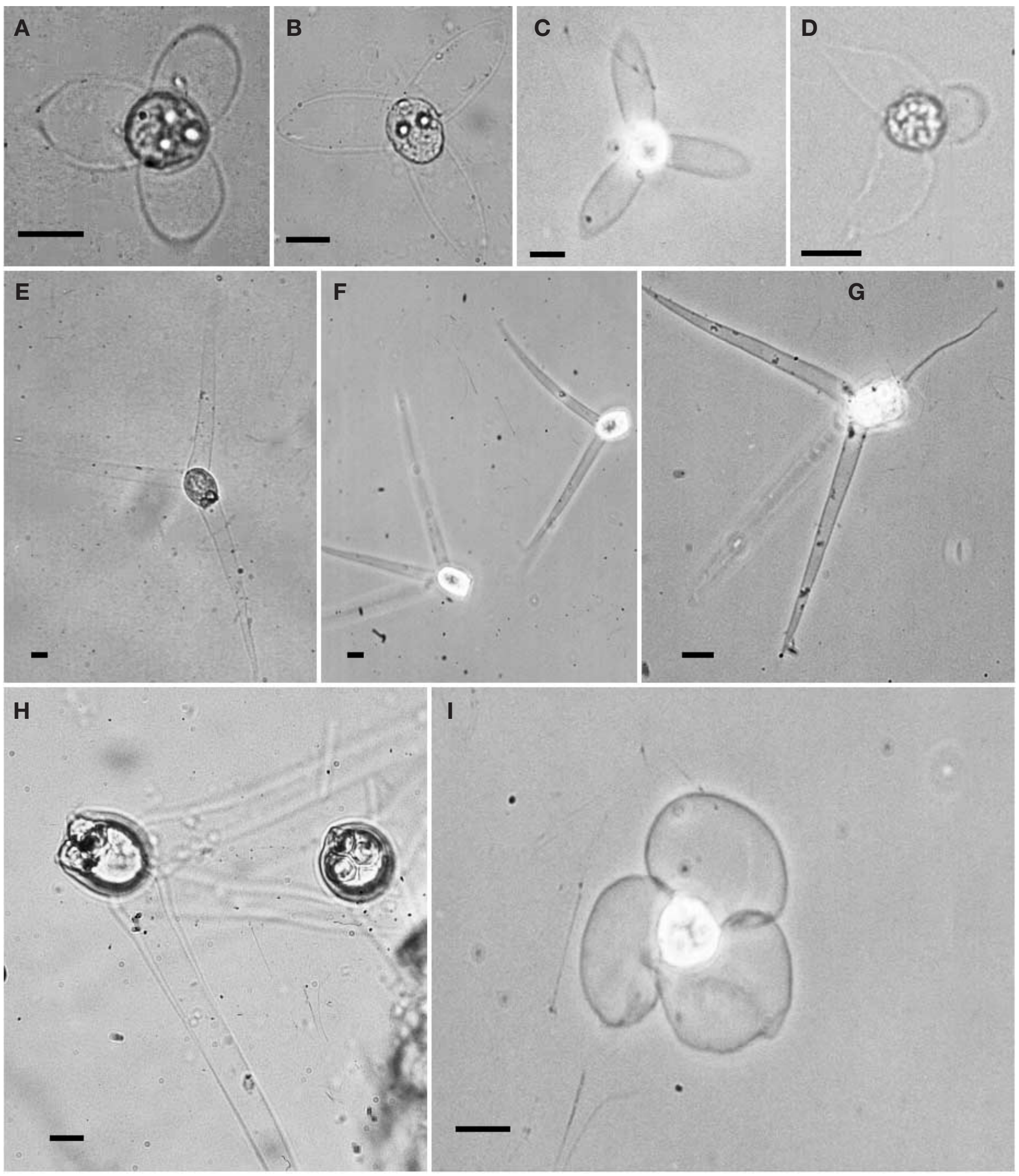

Fig. 3. Actinosporean forms found in the river system. (A-D) Aurantiactinomyxon; (A) type 1, (B,C) type 2, (D) type 3. (E-H)

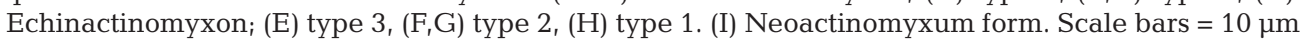



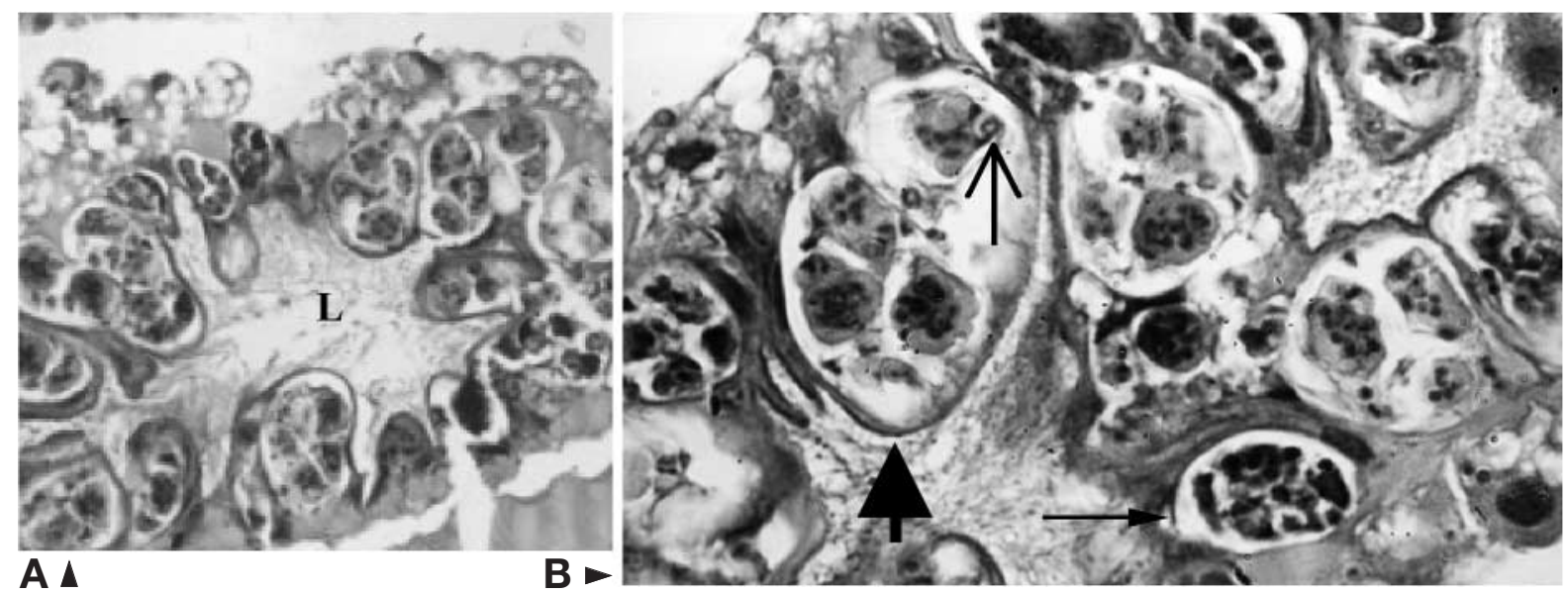

Fig. 4. Longitudinal sections of Tubifex ignotus infected with aurantiactinomyxon type 1. (A) Pansporocysts are located in the gut epithelium of the worm. (L) lumen. (H\&E) $(\times 200)$. (B) Pansporocysts stages seen at higher magnification. Large arrowhead indicates advanced stages of panporocysts containing mature spores. Infective cells can be observed inside the spore cavity of the spores. In some spores polar capsules are visible (open arrow). Small arrowhead indicates young pansporocysts $(\mathrm{H} \& \mathrm{E})(\times 400)$

Table 6. Summary of measurements for aurantiactinomyxon forms. $\bar{X}=$ mean, $\mathrm{SD}=$ standard deviation, Max. = maximum, Min. = minimum, $\mathrm{n}=$ no. of organisms measured. no $=$ measurements not obtained

\begin{tabular}{|c|c|c|c|}
\hline $\begin{array}{l}\text { Variables measured } \\
(\mu \mathrm{m})\end{array}$ & $\begin{array}{c}\mathrm{A} 1 \\
\mathrm{n}=43\end{array}$ & $\begin{array}{c}\mathrm{A} 2 \\
\mathrm{n}=12\end{array}$ & $\begin{array}{c}\mathrm{A} 3 \\
\mathrm{n}=4\end{array}$ \\
\hline \multicolumn{4}{|l|}{ Diameter of polar capsules } \\
\hline $\bar{X}$ & 3 & 2.7 & no \\
\hline SD & 0.3 & 0.2 & no \\
\hline Max. & 3.9 & 3.1 & no \\
\hline Min. & 2.5 & 2.6 & no \\
\hline \multicolumn{4}{|l|}{ Diameter of spore body } \\
\hline $\bar{X}$ & 14.4 & 14.1 & 9.1 \\
\hline SD & 1.3 & 1.3 & 0 \\
\hline Max. & 16.9 & 15.6 & 9.1 \\
\hline Min. & 12.6 & 13 & 9.1 \\
\hline \multicolumn{4}{|l|}{ Length of caudal processes } \\
\hline $\bar{X}$ & 21.1 & 31 & 20.8 \\
\hline $\mathrm{SD}$ & 1 & 3.7 & 1.8 \\
\hline Max. & 23.4 & 36 & 23.4 \\
\hline Min. & 18.2 & 26 & 18.2 \\
\hline \multicolumn{4}{|l|}{ Width of caudal processes } \\
\hline-1 & 16.1 & 10.6 & 10.4 \\
\hline $\mathrm{SD}$ & 2.1 & 1.1 & 0 \\
\hline Max. & 19.5 & 13 & 10.4 \\
\hline Min. & 13 & 9.1 & 10.4 \\
\hline
\end{tabular}

\section{Echinactinomyxon forms}

Three actinosporean types, presenting the characteristics of the echinactinomyxon form, were found during the study. The main features of this form are: style-less spores with equal and pointed caudal processes.

\section{Actinosporean form:}

echinactinomyxon 1 -Figs $2(\mathrm{G}) \& 3(\mathrm{H})$

Host: Lumbriculus variegatus

Description and measurements based on 13 organisms: The spore body was barrel-shaped, wider at its base than at its apex. Mean length was $22.4 \pm 1.6 \mu$ m (range, 18.2 to $23.4 \mu \mathrm{m}$ ) and width was $19.9 \pm 1.8 \mu \mathrm{m}$ (range, 14.7 to 20.8). The sporoplasmic mass included in the spore cavity contained 15 clearly visible germ cells, implying a minimum of 16 cells. Three oval-shaped polar capsules were prominent at the top of the spore. These were of length $7.3 \pm 0.7 \mu \mathrm{m}$ (range, 5.7 to $7.8 \mu \mathrm{m}$ ) and width $5.8 \pm 0.5 \mu \mathrm{m}$ (range, 5.2 to $6.5 \mu \mathrm{m}$ ). Caudal processes were long, robust and tapered to a point. They were of length $126 \pm 9.2 \mu \mathrm{m}$ (range, 117 to $143 \mu \mathrm{m}$ ) and width $13.3 \pm 0.8 \mu \mathrm{m}$ (range, 13 to $15.6 \mu \mathrm{m}$ ) (Table 7). Pansporocysts were located in the intestinal epithelium of the infected oligochaete.

\section{Actinosporean form:}

echinactinomyxon 2 -Figs $2(F) \& 3(F, G)$

Host: Lumbriculus variegatus

Description and measurements based on 4 organisms: The spore body had the shape of a cylinder, $13 \mu \mathrm{m}$ in width; length varied between 18.2 and $20.8 \mu \mathrm{m}$. Mean length was $19.6 \pm 1.2 \mu \mathrm{m}$. There were 25 infective cells clearly visible within the sporoplasmic mass. Caudal processes were straight, pointed and varied between 74.1 and $91 \mu \mathrm{m}$ in length and between 7.8 and $10.4 \mu \mathrm{m}$ in width. Mean length was $82.2 \pm 6.6 \mu \mathrm{m}$ and width $8.4 \pm 1.1 \mu \mathrm{m}$. The polar capsules at the apical part of the spore measured $6.6 \pm 0.8 \mu \mathrm{m}$ in width (range, 5.2 to 7.3 ) and $4.7 \mu \mathrm{m}$ in length (Table 7). Pansporocysts were located in the intestinal epithelium of the infected oligochaete. 
Table 7. Summary of measurements for echinactinomyxon forms. $\bar{x}=$ mean, $\mathrm{SD}=$ standard deviation, Max. = maximum, Min. $=$ minimum, $\mathrm{n}=$ no. of organisms measured

\begin{tabular}{|c|c|c|c|}
\hline $\begin{array}{l}\text { Variables measured } \\
(\mu \mathrm{m})\end{array}$ & $\begin{array}{c}\mathrm{E} 1 \\
\mathrm{n}=13\end{array}$ & $\begin{array}{c}\mathrm{E} 2 \\
\mathrm{n}=4\end{array}$ & $\begin{array}{c}\mathrm{E} 3 \\
\mathrm{n}=6\end{array}$ \\
\hline \multicolumn{4}{|l|}{ Width of polar capsules } \\
\hline $\bar{x}$ & 5.8 & 4.7 & 5.2 \\
\hline SD & 0.5 & 0 & 0 \\
\hline Max. & 6.5 & 4.7 & 5.2 \\
\hline Min. & 5.2 & 4.7 & 5.2 \\
\hline \multicolumn{4}{|l|}{ Length of polar capsules } \\
\hline $\bar{X}$ & 7.3 & 6.6 & 5.2 \\
\hline $\mathrm{SD}$ & 0.7 & 0.8 & 0 \\
\hline Max. & 7.8 & 7.3 & 5.2 \\
\hline Min. & 5.7 & 5.2 & 5.2 \\
\hline \multicolumn{4}{|l|}{ Length of spore body } \\
\hline $\bar{X}$ & 22.4 & 19.6 & 21.7 \\
\hline $\mathrm{SD}$ & 1.6 & 1.2 & 3.8 \\
\hline Max. & 23.4 & 20.8 & 26 \\
\hline Min. & 18.2 & 18.2 & 16.9 \\
\hline \multicolumn{4}{|l|}{ Width of spore body } \\
\hline 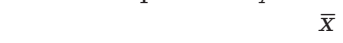 & 19.9 & 13 & 17.7 \\
\hline SD & 1.8 & 0 & 1 \\
\hline Max. & 20.8 & 13 & 18.2 \\
\hline Min. & 14.7 & 13 & 15.6 \\
\hline \multicolumn{4}{|l|}{ Length of caudal processes } \\
\hline $\bar{X}$ & 126 & 82.2 & 91 \\
\hline SD & 9.2 & 6.6 & 0 \\
\hline Max. & 143 & 91 & 91 \\
\hline Min. & 117 & 74.1 & 91 \\
\hline \multicolumn{4}{|l|}{ Width of caudal processes } \\
\hline $\bar{X}$ & 13.3 & 8.4 & 10.4 \\
\hline $\mathrm{SD}$ & 0.8 & 1.1 & 0 \\
\hline Max. & 15.6 & 10.4 & 10.4 \\
\hline Min. & 13 & 7.8 & 10.4 \\
\hline
\end{tabular}

\section{Actinosporean form:}

$\begin{array}{ll} & \text { echinactinomyxon } 3 \text {-Figs } 2(\mathrm{H}) \& 3(\mathrm{E}) \\ \text { Host: } & \text { Lumbriculus variegatus }\end{array}$ Description and measurements based on 6 organisms: The spore body showed shape similar to the echinactinomyxon 1 spore body. Mean length of the spore body was $21.7 \pm 3.8 \mu \mathrm{m}$ (16.9 to $26 \mu \mathrm{m}$ ) and width $17.7 \pm$ $1 \mu \mathrm{m}$ (range, 15.6 to $18.2 \mu \mathrm{m}$ ). Up to 13 germ cells were

Table 8. Summary of measurements for the neoactinomyxum form. $\bar{X}=$ mean, $\mathrm{SD}=$ standard deviation, Max. = maximum, Min. $=$ minimum . Measurements based on 10 organisms

\begin{tabular}{|lcccc|}
\hline Variables measured $(\mu \mathrm{m})$ & $\bar{X}$ & SD & Max. & Min. \\
\hline Width of polar capsules & 2.7 & 0.2 & 3.1 & 2.6 \\
Length of polar capsules & 3.8 & 0.2 & 3.9 & 3.1 \\
Length of spore body & 15.6 & 0 & 15.6 & 15.6 \\
Width of spore body & 12.9 & 0.1 & 13 & 12.7 \\
Length of caudal processes & 18.1 & 0.4 & 18.2 & 16.9 \\
Width of caudal processes & 25.6 & 1.2 & 26 & 22.1 \\
\hline
\end{tabular}

counted within the sporoplasmic mass. Polar capsules were spherical and measured $5.2 \mu \mathrm{m}$. Caudal processes were straight and tapered to a sharp point. They measured $91 \mu \mathrm{m}$ long by $10.4 \mu \mathrm{m}$ wide (Table 7). Pansporocysts were located in the intestinal epithelium of the infected oligochaete.

\section{Neoactinomyxum form}

Actinosporean form:

Host:

neoactinomyxum-Figs 2(D,E) \& 3(I) Lumbriculus variegatus

Description and measurements based on 10 organisms: Morphological characteristics observed in these forms corresponded with neoactinomyxum types. These spores were characterised by 3 rounded disc-shaped processes of equal size, which encircled the spore body. Caudal processes measured $18.1 \pm 0.4 \mu \mathrm{m}$ in length (range, 16.9 to $18.2 \mu \mathrm{m}$ ) and $25.6 \pm 1.2 \mu \mathrm{m}$ in width (range, 22.1 to $26 \mu \mathrm{m}$ ). Processes showed globular appearance in apical view but elongated shape in side view. The spore body, which was $15.6 \mu \mathrm{m}$ long $\times$ $12.9 \pm 0.1 \mu \mathrm{m}$ wide (range, 12.7 to $13 \mu \mathrm{m}$ ), was almost pyramidal when viewed from the top and elongated when viewed from the side. Up to 16 germ cells were counted within the sporoplasmic mass. Extending from the top of the spore, 3 oval-shaped polar capsules were evident. Mean width was $2.7 \pm 0.2 \mu \mathrm{m}$ (range, 2.6 to $3.1 \mu \mathrm{m}$ ). Mean length was $3.8 \pm 0.2 \mu \mathrm{m}$ (range, 3.1 to $3.9 \mu \mathrm{m}$ ) (Table 8). Pansporocysts were found located in the intestinal epithelium of the infected oligochaete.

\section{DISCUSSION}

Examination of the oligochaete samples from the study areas revealed the presence of 7 different actinosporean types belonging to 3 different groups, which were identified as aurantiactinomyxon, echinactinomyxon and neoactinomyxum forms based on comparisons with actinosporean types previously described in the literature. Three of these forms: aurantiactinomyxon 3, and echinactinomyxon 1 and 3, do not appear to have been described before. The remaining forms closely resemble forms described in the literature.

Identification of actinosporeans is currently based on comparisons of the morphological data of the spore. On the basis of morphological and morphometric characteristics, 4 actinosporean types described in this study closely compare with previously described forms. These are aurantiactinomyxon types 1 (A1) and 2 (A2), echinactinomyxon 2 (E2) and the neoactinomyxum type. According to the dimensions, A1 closely resem- 
Table 9. Comparison of the aurantiactinomyxon form described by Marques 1984 ('Aurantiactinomyxon pavinsis') with aurantiactinomyxon type 1 of this study

\begin{tabular}{|c|c|c|}
\hline Aurantiactinomyxon types & A1 & $\begin{array}{c}\text { 'A. pavinsis' } \\
\text { Marques (1984) }\end{array}$ \\
\hline Host & Tubifex ignotus & Stylodrilus heringianus \\
\hline Diameter of polar capsules $(\mu \mathrm{m})$ & $3(2.5-3.9)$ & Not recorded \\
\hline Diameter of spore body $(\mu \mathrm{m})$ & $14.4(12.6-16.9)$ & 12 \\
\hline Length of caudal processes $(\mu \mathrm{m})$ & $21.1(18.2-23.4)$ & $15-20$ \\
\hline Width of caudal processes $(\mu \mathrm{m})$ & $16.1(13-19.5)$ & Not recorded \\
\hline No. of germ cells & 10 & 12 \\
\hline
\end{tabular}

Table 10. Comparison of the aurantiactinomyxon form described by Styer et al. (1992) ('Aurantiactinomyxon minor') from ponds harbouring Proliferative Gill Disease (PGD) with aurantiactinomyxon type 2 of this study

\begin{tabular}{|c|c|c|}
\hline Aurantiactinomyxon types & $\mathrm{A} 2$ & $\begin{array}{c}\text { 'A. minor' } \\
\text { Styer et al. (1992) }\end{array}$ \\
\hline Host & Limnodrilus hoffmeisteri & Dero digitata \\
\hline Diameter of polar capsules $(\mu \mathrm{m})$ & $2.7(2.6-3.1)$ & Not recorded \\
\hline Diameter of spore body $(\mu \mathrm{m})$ & $14.1(13-15.6)$ & $13-16$ \\
\hline Length of caudal processes $(\mu \mathrm{m})$ & $31(26-36)$ & 36 \\
\hline Width of caudal processes $(\mu \mathrm{m})$ & $10.6(9.1-13)$ & 11 \\
\hline No. of germ cells & 12 & Not recorded \\
\hline
\end{tabular}

Table 11. Comparison of 'Echinactinomyxon radiatum' (Janiszewska 1957, Marques 1984) with echinactinomyxon form found in this study

\begin{tabular}{|c|c|c|}
\hline Echinactinomyxon types & $\mathrm{Ja}$ & $\begin{array}{c}\text { 'E. radiatum' } \\
\text { aniszewska (1957) } \\
\text { Marques (1984) }\end{array}$ \\
\hline Host & Lumbriculus variegatus & Tubifex tubifex \\
\hline Diameter of polar capsules $(\mu \mathrm{m})$ & $6.6(5.2-7.3)$ & 6 \\
\hline Diameter of spore body $(\mu \mathrm{m})$ & $19.6(18.2-20.8)$ & $20-25$ \\
\hline Length of caudal processes $(\mu \mathrm{m})$ & $82.2(74-91)$ & $100-125$ \\
\hline No. of germ cells & 26 & $32(20-32)$ \\
\hline
\end{tabular}

Table 12. Comparisons of 'N.sp' (Morris 1996) with neoactinomyxum form found in this study

\begin{tabular}{|lcc|}
\hline Neoactinomyxum types & $\begin{array}{c}\text { Neoactinomyxum } \\
\text { (this study) }\end{array}$ & $\begin{array}{c}\text { 'N.sp' } \\
\text { (Morris 1996) }\end{array}$ \\
\hline Host & Lumbriculus variegatus & Tubifex sp. \\
Diameter of spore body $(\mu \mathrm{m})$ & $12.9 \times 15.6$ & $16(15-17)$ \\
Length of caudal processes $(\mu \mathrm{m})$ & $18.1(16.9-18.2)$ & $13(12-15)$ \\
Width of caudal processes $(\mu \mathrm{m})$ & $25.6(22-26)$ & $23(22-24)$ \\
No. of germ cells & 16 & Not recorded \\
\hline
\end{tabular}

bles the large form of 'Aurantiactinomyxon pavinsis', which was recorded by Marques (1984) in France (Table 9). A2 identified more closely with ' $\mathrm{Au}$ rantiactinomyxon minor' described by Styer et al. (1992) from ponds infected with Proliferative Gill Disease in the USA containing channel catfish Ictalurus punctatus (Table 10); E2 identified closely with 'Echinactinomyxon radiatum', described by Janiszewska (1957) in Poland and Marques (1984) in France (Table 11); and the neoactinomyxum form identified closely with 'N.sp' found by Morris in Southern England (1996) (Table 12).

Identification of actinosporeans was difficult and several problems were encountered. Firstly, although morphological similarities were found, it is difficult to establish correspondence between these forms with any confidence as they belong to different habitats with foreign host species. In order to establish a correspondence between actinosporean types, molecular studies are required. Difficulties were also found when comparing with some actinosporean descriptions performed in the past, as these were incomplete. Aurantiactinomyxon types involved in the transmission of Myxidium giardi found by Benajiba \& Marques (1993), and the neoactinomyxum recorded by Yokoyama et al. (1993a), could not be compared with those of this study as these authors provided only a picture or a drawing of the spore, without details of its measurements.

Aurantiactinomyxon 3 (A3) was considered to be a previously unrecorded actinosporean type, as no comparable aurantiactinomyxon form was found in the literature. However, it is possible that $\mathrm{A} 3$ was an aberrant case of A1. A3 was included in the aurantiactinomyxon group, based on the absence of style and the presence of 3 lateral elongated caudal processes of equal length embracing the spore body by their bases. Although A3 presents the main characteristics of the aurantiactinomyxon group, this spore is distinguishable from described forms of aurantiactinomyxon in the shape of 1 
spore caudal process that differs from the other two. Aberrant spores have been shown to be common in myxosporean developments (Shulman 1966). Despite its morphological differences with A1 spores, A3 closely resembles A1, and both forms were observed infecting species of Tubifex ignotus. A3 spores were rare, being released only in very low numbers and from a single specimen. However, no mixed infections were recorded in an individual infected oligochaete.

Echinactinomyxon types 1 and 3 are also considered to be new actinosporean types, as they do not resemble any previous descriptions in the literature (Janiszewska 1957, Marques 1984, Xiao \& Desser 1998b).

In relation to the forms studied here, no comparable forms were found among aurantiactinomyxon described by Marques (1984), Pote \& Waterstrat (1993), Trouillier et al. (1996), Yokoyama et al. (1993a, 1997), McGeorge et al. (1997), El-Mansy et al. (1998), nor the echinactinomyxon described by Janiszewska (1957), Marques (1984), Xiao \& Desser (1998b) nor the neoactinomyxum described by Marques (1984), El-Mansy et al. (1998) and Xiao \& Desser (1998b). Variations in dimensions, locality, alternative host or spore structure were noticed.

In this study the overall prevalence of infection with actinosporeans was $2 \%$, which agrees with previous studies. Prevalence of actinosporean infections in the wild is often low (between 1 and $3 \%$, Lom et al. 1997).

The highest prevalence of actinosporean infection was found with aurantiactinomyxon 1 in Tubifex ignotus. This actinosporean type was recorded in high numbers on all 3 sampling occasions. In contrast, echinactinomyxon 1, echinactinomyxon 3 and aurantiactinomyxon 3 were released in very low numbers and always from a single infected specimen.

Echinactinomyxon 2 and aurantiactinomyxon 2 were released in low numbers and they were less frequent and prevalent than aurantiactinomyxon 1. Prevalence data obtained for aurantiactinomyxon 2 cannot be considered reliable as only mature host specimens could be identified. The neoactinomyxum form, although being found only 4 times on 2 occasions, displayed heavy infections and the host Lumbriculus variegatus was observed to release large numbers of spores.

It could be expected that the actinosporeans found in this study have associated myxosporean stages in their life cycles, as forms of the aurantiactinomyxon, echinactinomyxon and neoactinomyxum groups have been previously shown to be linked to a number of myxosporeans infecting fish. However, the associated myxosporean stages of the actinosporeans described in this study are unknown. Native fish from the river system sampled include eel Anguilla anguilla, minnow Phoxinus phoxinus, brown trout Salmo trutta and Atlantic salmon Salmo salar (Roche 1991). One study is avail- able on the myxosporean fauna occurring in the river system (O'Flynn 1998). The information includes monthly sampling for $1 \mathrm{yr}$ and seasonal sampling for 2 yr. Myxosporean species recorded were Myxidium giardi and M. rhodei from eel, and Myxobolus sp. and Chloromyxum sp. from Atlantic salmon and brown trout. The highest prevalences of infection were recorded for Myxidium giardi and Myxobolus sp. (O'Flynn 1998) Low prevalence of infection was recorded for the remaining myxosporean species. Comparison of prevalence data for actinosporeans from this study with prevalence of Myxosporea from O'Flynn (1998) does not allow any conclusions to be drawn. However, the results obtained for aurantiactinomyxon type 1 were interesting, as this actinosporean type was recorded from the 3 sampling occasions and in high numbers. $M$. giardi is the only myxosporean species found in the river system for which the actinosporeanassociated stage is known. An aurantiactinomyxon form is involved in the life cycle of this myxosporean species, but only an incomplete description of this stage was given by Benajiba \& Marques (1993), which makes comparison difficult. The life cycles of $M$. rhodei, Myxobolus sp. and Chloromyxum spp. still remain unknown.

Establishing a relationship between myxosporeans and any of the actinosporean forms recorded in this study will require experimental transmission studies and molecular biological methods. Ultrastructural and molecular studies based on comparisons of ribosomal DNA are in progress.

Acknowledgements. We thank Dr Tom C. Kelly for his helpful review of this manuscript.

\section{LITERATURE CITED}

Bartholomew J, Whipple MJ, Stevens DG, Fryer JL (1997) The life cycle of Ceratomyxa shasta, a myxosporean parasite of salmonids, requires a freshwater polychaete as an alternate host. J Parasitol 83:859-868

Benajiba MH, Marques A (1993) The alternation of actinomyxidian and myxosporidian sporal forms in the development of Myxidium giardi (parasite of Anguilla anguilla) through oligochaetes. Bull Eur Assoc Fish Pathol 13: 100-103

Brinkhurst RO (1971) A guide for the identification of British Aquatic Oligochaeta. Freshw Biol Assoc Sci Publ 22:1-52

El-Mansy A, Molnár K (1997) Extrapiscine development of Myxobolus drjagini Akmerov, 1954 (Myxosporea: Myxobolidae) in oligochaete alternative hosts. Acta Vet Hung 45:427-438

El-Mansy A, Székely Cs, Molnár KA (1998) Studies on the occurrence of actinosporean stages of fish myxosporeans in a fish farm of Hungary, with the description of triactinomyxon, raabeia, aurantiactinomyxon and neoactinomyxon types. Acta Vet Hung 46(2):259-284

El-Matbouli M, Hoffmann RW (1989) Experimental trasmission of two Myxobolus spp. Developing bisporogeny via tubificid worms. Parasitol Res 75:461-464 
El-Matbouli M, Hoffmann RW (1993) Myxobolus carassii Klokaceva, 1914 also requires an aquatic oligochaete, Tubifex tubifex as an intermediate host in its life cycle. Bull Eur Assoc Fish Pathol 13:189-192

El-Matbouli M, Fischer-Scherl T, Hoffmann RW (1992) Transmission of Hoferellus carassii Achmerow, 1960 to goldfish Carassius auratus via an aquatic oligochaete. Bull Eur Assoc Fish Pathol 12:54-56

Großheider G, Körting W (1992) First evidence that Hoferellus cyprini (Doflein, 1898) is transmitted by Nais sp. Bull Eur Assoc Fish Pathol 12:17-20

Janiszewska J (1955) Actinomyxidia. Morphology, ecology, history of investigation, systematics, development. Acta Parasitol Pol 2:405-437

Janiszewska J (1957) Actinomyxidia II. New systematics, sexual cycle, description of new genera and species. Zool Pol 8:3-34

Kent ML, Whitaker DJ, Margolis L (1993) Transmission of Myxobolus arcticus Pugachev and Khoklov, 1979 a myxosporean parasite of Pacific salmon, via a triactinomyxon from the aquatic oligochaete Stylodrilus heringianus (Lumbriculidae). Can J Zool 71:1207-1211

Kent ML, Margolis L, Corliss JO (1994) The demise of a class of protists: taxonomic and nomenclatura revisions proposed for the protist phylum myxozoa Grasse, 1970. Can J Zool 72:932-937

Lom J, Dyková I (1992) Protozoan parasites of fishes. Developments in Aquaculture and Fisheries Science 26. Elsevier Science, Amsterdam

Lom J, McGeorge J, Feist SW, Morris D, Adams A (1997) Guidelines for the uniform characterisation of the actinosporean stages of parasites of the phylum Myxozoa. Dis Aquat Org 30:1-9

Marques A (1984) Contribution à la connaissance des Actinomyxidies: ultrastructure, cycle biologique, systematique. $\mathrm{PhD}$ thesis, Universite des Sciences et Techniques du Languedoc, Montpellier

McGeorge J, Sommerville C, Wootten R (1997) Studies of actinosporean myxozoan stages parasitic in oligochaetes from the sediments of a hatchery where Atlantic salmon harbour Sphaerospora truttae infection. Dis Aquat Org 30:107-119

Molnar K, El-Mansy A, Székely C, Baska F (1999) Experimental identification of the actinosporean stage of Sphaerospora renicola Dykova \& Lom 1982 (Myxosporea: Sphaerosporidae) in oligochaete alternate hosts. J Fish Dis 22:143-153

Morris D (1996) Studies on Proliferative Kidney Disease using monoclonal antibody probes. PhD thesis, University of Stirling

Oumouna M (1998) Vorkommen von Oligochaeten als Wirte für Proliferative Kidney Disease (PKD) enzootischen Forellenbetrieb. PhD thesis, Universität München

O'Flynn J (1998) Studies of the biology \& lifecycle of PKX, the causative agent of Proliferative Kidney Disease. PhD thesis, University College Cork, National University of Ireland

Özer A, Wootten R (2000) The life cycle of Sphaerospora truttae (Myxozoa: Myxosporea) and some features of the biology of both the actinosporean and myxosporean stages. Dis Aquat Org 40:33-39

Pote LM, Waterstrat P (1993) Motile stage of Aurantiactinomyxon sp. (Actinosporea:Triactinomyxidae) isolated from
Dero digitata found in channel catfish ponds during outbreaks of proliferative gill disease. J Aquat Anim Health $5: 213-218$

Roche W (1991) A fishery survey of the Cloonee lakes catchment, Kenmare, Co. Kerry. Central Fisheries Board, Dublin

Ruidisch S, El-Matbouli M, Hoffmann RW (1991) The role of tubificid worms as an intermediate host in the life cycle of Myxobolus pavlovskii Achmerov, 1954. Parasitol Res 77: 663-667

Shulman SS (1966) Myxosporidia of the fauna of the USSR. Nauka, Moscow (in Russian)

Styer EL, Harrison LR, Burtle GJ (1992) Six new species of actinomyxids from Dero digitata. International workshop on myxosporeans. October 6-8, 1992. České Budéjovice (abstract)

Székely C, El-Mansy A, Molnar K, Baska F (1998) Development of Thelohanellus nikolskii (Myxosporea: Myxozoa) in oligochaete alternate hosts. Fish Pathol 33(3):107-114

Trouillier A, El-Matbouli M, Hoffmann W (1996) A new look at the life-cycle of Hoferellus carassii in the goldfish (Carassius auratus) and its relation to 'kidney enlargement disease' (KED). Folia Parasitol 43:173-187

Uspenskaya AV (1995) Alternation of actinosporean and myxosporean phases in the life cycle of Zschokkella nova (Myxozoa). J Eukaryot Microbiol 42:665-668

Wolf K, Markiw ME (1984) Biology contravenes taxonomy in the Myxozoa: new discoveries show alternation of invertebrate and vertebrate hosts. Science 225:1449-1452

Xiao C, Desser SS (1998a) Actinosporean stages of myxozoan parasites of oligochaetes from lake Sasajewun, Algonquin Park, Ontario: new forms of triactinomyxon and raabeia. J Parasitol 84(5):998-1009

Xiao C, Desser SS (1998b) Actinosporean stages of myxozoan parasites of oligochaetes from lake Sasajewun, Algonquin Park, Ontario: new forms of echinactinomyxon, neoactinomyxon, aurantiactinomyxon, guyenotia, synactinomyxon, and antonactinomyxon. J Parasitol 84(5):1010-1019

Xiao C, Desser SS (1998c) The oligochaetes and their actinosporean parasites in lake Sasajewun, Algonquin Park, Ontario. J Parasitol 84(5):1020-1026

Yokoyama H (1997) Transmission of Thelohanellus hovorkai Achmerov, 1960 (Myxosporea: Myxozoa) to common carp Cyprinus carpio through the alternate oligochaete host. Syst Parasitol 36:79-84

Yokoyama H, Owaga K, Wakabayashi H (1991) A new collection method of actinosporeans. A probable infective stage of myxosporeans to fishes from tubificids and experimental infection of goldfish with the actinosporean, Raabeia sp. Fish Pathol 26:133-138

Yokoyama H, Owaga K, Wakabayashi H (1993a) Involvement of Branchiura sowerbyi (Oligochaeta: Annelida) in the transmission of Hoferellus carassii (Myxosporea: Myxozoa), the causative agent of kidney enlargement disease (KED) of goldfish Carassius auratus. Fish Pathol 28:135-139

Yokoyama H, Owaga K, Wakabayashi H (1993b) Some biological characteristics of actinosporean from the oligochaete Branchiura sowerbyi. Dis Aquat Org 17:223-228

Yokoyama H, Owaga K, Wakabayashi H (1995) Myxobolus cultus n.sp (Myxosporea: Myxobolidae) in the goldfish Carassius auratus transformed from the actinosporean stage in the oligochaete Branchiura sowerbyi. J Parasitol $81: 446-451$ 